\title{
CONSERVATION OF MANGROVES IN KUALA PERLIS, MALAYSIA-A CASE STUDY OF SOCIO-ECONOMIC ATTRIBUTES OF FISHERMEN DRIVING VALUATION IN SUSTAINING LIVELIHOODS THROUGH FOREST MANAGEMENT
}

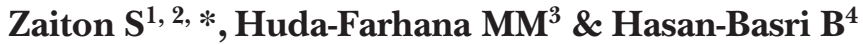 \\ ${ }^{1}$ Faculty of Economics and Management, Universiti Putra Malaysia, 43400 UPM Serdang, Selangor, Malaysia \\ ${ }^{2}$ Institute of Tropical Forestry and Forest Products, Universiti Putra Malaysia, 43400 Serdang, Selangor, Malaysia \\ ${ }^{3}$ Social Forestry Programme, Forest Research Institute Malaysia (FRIM), 52109 Kepong, Selangor, Malaysia \\ ${ }^{4}$ Department of Economics and Agribusiness, School of Economics, Finance and Banking, Universiti Utara Malaysia, \\ Sintok, Kedah, Malaysia \\ *zaisa@upm.edu.my
}

Submitted April 2019; accepted October 2019

\begin{abstract}
A mangrove ecosystem provides a wide range of services which benefit people, society and the economy at large. Local communities are highly dependent on mangrove ecosystems especially for food resources, firewood, charcoal, timber, etc. Mangrove forests are important to fishermen for sustaining rich seafood supplies as a source of income, however due to land conversion to aquaculture and coastal development, mangrove deforestation is faced. Thus it is important that the mangroves in Kuala Perlis are conserved and used by the local community for fishing and aquaculture activities. The fishery sector has a significant impact on the socio-economics of the local community. Face-to-face interviews were conducted among these fishermen. A binary logit model, specifically the Contingent Valuation Method (CVM) was used to determine factors that influenced the fishermen's willingness to pay (WTP) for conservation. The logit model is one of the most preferred methods that is used to model binary dependent variables in the presence of more than one explanatory variable. The results indicated that the WTP of fishermen was significantly influenced by bid level, education level and marital status. It also shows that socio-demographic factors also influenced the respondent's willingness to pay for the conservation of nature. These WTP factors are crucial in providing information for better policy options to decision-makers in designing sustainable mangrove forest management for the benefit of the future generations in Malaysia.
\end{abstract}

Keywords: Contingent valuation method, willingness to pay, conservation, mangrove

\section{INTRODUCTION}

Mangrove swamps, directly and indirectly, are of important economic, ecological and social value to humans. Das and Crepin (2013) believed that mangrove forests are among the most productive ecosystems in the world and their importance is ecologically, economically and culturally wellestablished. Local communities directly benefit from mangroves through the utilisation of fishery and forestry products (Shervette et al. 2007). Mangroves also provide several necessities as part of estuarine and coastal ecosystems. Wells et al. (2006) asserted that the services provided by a mangrove ecosystem are beneficial for socioeconomic development. Constanza et al. (1997) added that a mangrove ecosystem provides valuable ecosystem services that benefit human welfare.

Ecosystems provide a range of services, many of which are important to the well-being of humans, such as for health, livelihood and survival (Constanza et al. 1997, TEEB 2010). A mangrove forest ecosystem is considered to be a complex ecosystem because of its relationship to humans, wildlife, flora, fauna and marine life. Although the importance of mangrove ecosystems to human society has many dimensions, determining and capturing the economic values of these ecosystem services is a 
crucial tool for raising awareness and to conserve the environment (Groot et al. 2012). Pertinent and accurate information of the economic values leads to efficient use of government funds by identifying the issues and areas where conservation is critical and economically viable at the lowest cost possible.

Conservation is the insurance, protection, administration and reclamation of common habitats and biological groups that possess them. Conservation of the environment is the protection, preservation, management or restoration of natural environments and the ecological communities that inhabit them. It includes the management of natural resources for public benefits and sustainable social and economic utilisation. The act of conserving includes prevention of injury, decay and waste or loss, which leads to preservation and conservation of wildlife and human rights. Official supervision of rivers, forests and other natural resources is needed in order to preserve and protect them through prudent management. Careful utilisation of these natural resources must be made in order to restore and to prevent their depletion (Zaiton et al., 2012).

Fisheries industries and other sectors with fishermen will only be sustained through conservation and protection of the mangrove forests. Recently, mangrove and it's services have been increasingly recognised, however more attention was focused on fisheries and wood harvesting values. Limited studies were found on the identification of non-use value, option value and existence value related to mangrove ecosystem, including factors influencing the willingness to pay for these values. One of the advantages of Contingent Valuation Method (CVM) is the ability to estimate the economic value of ecosystem by asking people to state their willingness to pay in a hypothetical market (Vegh et al. 2014). The willingness to pay for mangrove conservation is influenced by many factors such as income, education level, marital status etc. The findings will help policy makers in designing conservation activities that will protect the mangrove.

For example, the fishermen in Kuala Perlis are highly dependent on mangrove. Thus, they are important stakeholders to conserve the mangrove. In addition, the fishery sector in Kuala Perlis has a significant impact on the income generation of local people. The purpose of this study is to examine the factors influencing fishermen's willingness to pay for mangrove conservation in Kuala Perlis. This assessment will provide baseline information to conserve and maintain mangrove forest ecosystems for future generations by designing conservation programs that could encourage mangrove conservation among fishermen.

\section{Contingent valuation method}

The CVM is one of the methods used to estimate the economic value of environmental goods and services. It is widely used in areas of economics such as in health, cultural and environmental economics as well as in transportation safety economics. It is a simple, straightforward and flexible method which has been widely used in environmental valuation. The CVM is considered to be one of the most promising methods for valuing public goods and environmental products (Mitchell \& Carson 1989, Pearce \& Turner 1990, Arrow et al. 1993).

Ajzen and Driver (1992) stated that CVM is a tool used to place an amount of money for goods and service that usually do not have a place in the market. The CVM also evaluates all types of ecosystems and services related to the environment. This method is used to assess direct or indirect usage (Zaiton et al. 2012). The CVM gives an empirical estimation of use and non-use values. In a contingent valuation study, five formats were used in the application of contingent valuation: open-ended WTP, iterative bidding, Dichotomous Choice (DC), contingent ranking and payment ladder (Garrod and Willis 1999).

The format applied in this study was Dichotomous Choice (DC). The DC is also called the referendum format approach and it is the most frequently recommended form for CVM questionnaires (Mitchell \& Carson 1989, Desvousges et al. 1993). The main advantage of the DC method is that it is like a 'take it or leave it' (TIOLI) approach, since the situation presented is similar to consumers making a purchase of ordinary goods and services. In fact, this approach reduces biases in CVM (such as strategic, design and interviewer biases) compared to other elicitation approaches (Mitchell \& Carson 1989). Using the DC format, a respondent was asked whether he would be willing to pay a stated monetary value. A "yes" 
answer was given if the true WTP was in excess of the stated monetary value and a "no" answer indicated otherwise. The DC was divided into single and double-bounded. Single-bounded was used for only one price bid, which was offered on the response of either "yes" or "no".

\section{Determinants of willingness to pay}

Various determinants have been identified by previous studies. According to Bhandari and Heshmati (2010), the important determinants of WTP include some socio-demographic and other variables such as past payment history, length of stay, visitor satisfaction and attitudes towards the environment. Bloom and Shenglan (1999) and Atim (1999) asserted that socioeconomic and economic characteristics will influence WTP. Bowker et al. (1999) used various socio-demographic variables including gender, education, household size, race, income and geography in determining user fees for conservation.

One of the important determinants is income. Fatin et al. (2017) found that the income of fishermen is positively related to willingness to pay for mangrove conservation in the Matang Mangrove Forest Reserve. Ezebilo (2016) concluded that among the income groups, lowincome earners have the lowest WTP and highincome earners have the highest WTP. Zaiton et al. (2010) also used CVM and found that one of the determinants that influence visitors' WTP on natural resources in Taman Negara National Park is income. Rathnayake (2016) also found that income is an important factor that increases the WTP for marine turtle conservation in Sri Lanka. Other studies also found a positive relationship between the income variable and willingness to pay (White \& Lovett 1999, Tisdell \& Wilson 2000, Jacobsen \& Hanley 2008, Brouwer et al. 2016, Fatin et al. 2017).

The level of education is another important variable that influences people's willingness to pay. Jin et al. (2018) found that respondent with a higher education level is more willing to support the marine turtle conservation program. This finding is understandable given the assumption that more years of schooling can help respondents to better understand environmental problems and the importance of biodiversity conservation (Jin et al. 2018). It can be hypothesised that the level of education has a positive impact on WTP.
The next demographic variable is age, an essential variable that has a significant effect and influences a person's willingness to pay for nature conservation. The importance of age has been reported in many studies (Mamat et al. 2013). According to Baral et al. (2008), age is often positively related to the WTP for conservation. On the other hand, Landry et al. (2003) found that age has a negative effect on WTP, compared to younger people, older people are not willing to contribute towards conservation. Thus, previous studies noted that the age variable has both positive and negative effects on respondents' willingness to pay.

Ezebilo (2016) found that men paid more than women for the conservation of Mount Wilhelm, Papua New Guinea. Schaafsma et al. (2014) found that male respondents expressed higher WTP to protect the lake than did the female respondents, and were more probable to give a "yes" answer to requests for contributions. On the other hand, in the study by Zaiton et al. (2010), the results showed that price, household size, household income, family members below the age of 12 , females and respondents with higher education level are more willing to pay for entrance fee in Taman Negara National Park. Compared to men, the more compassionate nature of women makes them willing to pay for conversation and protection. The study concluded that women who are mothers are probably more responsible and willing to pay any amount because they are concerned that their children and the future generations should inherit a healthier earth. The studies carried out by White and Lovett (1999) and Kaffashi et al. (2015) found that gender plays an important part in willingness to pay.

Another important demographic variable is the marital status of a person. Marital status positively influenced the respondents' WTP. It was found that single respondents were more willing to pay compared to the married respondents. This was because those who were married spent more on their families, compared to the single respondents. The responsibilities of a single respondent are lower compared to the married and divorced respondents. The study by Zaiton et al. (2010) showed that the willingness to pay for an entrance permit at Taman Negara National Park was influenced by the visitor's income, nationality, education level and marital status. This study found that marital status is a significant factor in determining a person's 
WTP as the married respondents in the study indicated a willingness to pay more because they wanted their children and future generations to enjoy what they were currently enjoying, such as the scenic beauty of the national park. In other words, it can be said that the parents or married respondents wanted to conserve the rainforest for the benefit of future generations. According to Lalika et al. (2017), marital status, household size and distance from water sources positively influence a respondent's WTP for watershed conservation. The WTP for watershed conservation increases in married people.

\section{MATERIALS AND METHODS}

\section{Study area}

The study was conducted in a mangrove area in Kuala Perlis, Perlis. Perlis is the smallest state in Malaysia, located at the northern part of the west coast of Peninsular Malaysia. The state shares borders with the Satun and Songkhla Provinces of Thailand to the north and Kedah to the south. Based on the computation of mangrove forest using satellite imagery from Google Earth (2019), there are about 12 hectares of mangroves located in Kuala Perlis and the remaining 52 hectares placed around the state of Perlis.

\section{Sampling and data collection}

The information utilised in this study comprised of primary and secondary data. The primary data were taken from personal interviews with fishermen, using questionnaires. In this study, purposive sampling was chosen as the sampling technique, instead of probability sampling because it gives the most effective results (Tongco 2007). The samples were purposely selected based on the occupation of the respondents. Purposive sampling is a nonprobability sampling where sample is selected based on his or her judgement about some appropriate characteristics (Zikmund et al. 2013). Dong et al. (2011) used purposive sampling to measure recreational value using CVM in Jiuzhaigou. An accurate estimation of CVM depends on the sample size. A total number of local fishermen in Kuala Perlis was recorded as 1498 in the year 2017 (Fisheries Department 2018). According to Zikmund et al. (2013), based on the above number of population, estimation of sample size is 278 . This study conducted face-to-face interview of 300 fishermen at the fishermen's jetty, at Kompleks Lembaga Kemajuan Ikan Kuala Perlis.

For this study, Dichotomous Choice (DC) option was applied. This format, recommended by the National Oceanic and Atmospheric Administration (NOAA) panel, has advantages over other elicitation methods such as open ended, bidding games and payment cards. The hypothetical question for WTP assessment was, "If you are required to pay RM X per year to the conservation fund to conserve mangroves in Kuala Perlis, are you willing to pay?" The DC approach is a method for obtaining information from respondents about WTP by providing an initial bid in which the respondents will be asked whether they are willing to pay the amount specified for the service. The bid price range used was based on a pilot survey carried out on fishermen in Kuala Perlis mangrove. A set of structured questions were used to collect information. The set of prices used in this study consisted of RM1, RM5, RM10, RM15, RM20 and RM25. The data collected were analysed using the logit model. Stata software version 12 was used to estimate the parameters of the logit model.

\section{Model specification}

In this study, the logit model was applied to explore the factors influencing willingness to pay a fee for the conservation of the mangroves in Kuala Perlis among fishermen. The logistic model was chosen for its ability to manage dichotomous dependent variables (Parid et al. 2014). Pampel (2000) asserted that it can handle non-linear effects and the dependent variable need not be normally distributed. The logit model is as follows:

$$
\mathrm{P}_{\mathrm{i}}=\mathrm{E}\left(\mathrm{Y}=1 / \mathrm{X}_{\mathrm{i}}\right)=\left[1 /\left\{1+\mathrm{e}^{-\left(\beta_{0}+\beta_{\mathrm{i}} \sum \mathrm{X}_{\mathrm{i}}\right)}\right\}\right]
$$

Where $\mathrm{P}_{\mathrm{i}}=$ probability of $\mathrm{Y}=1, \mathrm{X}_{\mathrm{i}}=\mathrm{a}$ set of independent variables and $\beta_{i}=$ estimated coefficient corresponding to logistic distribution

When natural logarithm was taken from equation above, it acquired the following equation:

$$
\mathrm{L}_{\mathrm{i}}=\ln \left\{\mathrm{P}_{\mathrm{i}} /\left(1-\mathrm{P}_{\mathrm{i}}\right)\right\}=\beta_{0}+\beta_{\mathrm{i}} \sum \mathrm{X}_{\mathrm{i}}+\mathrm{e}_{\mathrm{i}}
$$

where $\mathrm{L}_{\mathrm{i}}$ is logit and is the $\log$ of all odd ratios and linear in both independent variable and 
its parameters (Khan \& Giurca 2008). The Maximum Likelihood Estimator (MLE) was used as the means of estimation methods. The logistic regression model has an S-shape distribution function. It simplifies a non-linear transformation of linear regression. The estimation probability is (Hanemann et al. 1991, Wang \& Jia 2012):

$$
\mathrm{p}=1 /[1+\exp (-\alpha-\beta \mathrm{X})
$$

where,

$\mathrm{Y}=$ a dummy dependent variable $(\mathrm{YES}=1, \mathrm{NO}=0)$

$\mathrm{P}=$ the probability that the event Yoccurs, $\mathrm{p}(\mathrm{Y}=1)$

$\alpha=$ the coefficient on the constant term

$\beta=$ the coefficient $(\mathrm{s})$ on the independent variable (s)

$\mathrm{X}=$ the independent variable $(\mathrm{s})$

Table 1 shows the description of variables used in this study. Independent variables in this study include socio-economic and demographic characteristics which, in turn, include factors such as gender, income, educational level, marital status and age. Other independent variables include bid price. Due to lack of studies done in Malaysia to determine the factors associated with mangrove conservation among fishermen, this study initiates basic model focusing on socio-demographic and economic characteristics. The aim of this study is to fill the information gap in understanding significance factors influencing the decision to conserve the mangroves ecosystem. Findings from this study will be used to develop comprehensive models. Associating more factors into the analysis will lead to understanding conservation behaviour among different groups of community.

\section{RESULTS}

\section{Socio-demographic characteristics}

Table 2 shows the full background information of the respondents at Kuala Perlis. Most (85\%) of the fishermen interviewed were male. The majority of the respondents were Malay (98.3\%), followed by four Chinese $(1.3 \%)$ and one Indian $(0.3 \%)$. The majority of the respondents interviewed were in the 51-60 years of age category. The second biggest group comprised the senior citizens, followed by those in the 41-50 years of age category. In addition, the majority $(84.7 \%)$ of the respondents were married. Of those who were married, the majority of them (59\%) came from households of between three and five family members living together.

In terms of education, most $(39.7 \%)$ of the fishermen had been educated up to upper secondary school level (11 years of education). The income level of the respondents was relatively low with $78 \%$ of them earning only RM1,000 and below per month. The socio-economic results showed that, in general, the respondents were fully dependent on marine activities as the source of their monthly incomes.

\section{Reasons for paying}

Table 3 lists the various reasons that the respondents were willing to pay the bid level. A total of 151 respondents $(62.1 \%)$ expressed

Table 1 Description of variables

\begin{tabular}{lll}
\hline Variables & \multicolumn{1}{c}{ Type } & \multicolumn{1}{c}{ Description } \\
\hline Bid & Continuous & $\begin{array}{l}\text { The amount of first bid proposed for RM1, 5, } \\
10,15,20 \text { or 25 per year }\end{array}$ \\
\hline $\begin{array}{l}\text { Socioe-conomic and demographic } \\
\text { characteristics } \\
\text { Gender }\end{array}$ & Categorical & $\begin{array}{l}\text { Dummy variables equal } 1 \text { if the respondent is } \\
\text { male and 0 otherwise. }\end{array}$ \\
$\begin{array}{l}\text { Income } \\
\text { Education level } \\
\text { Marital status }\end{array}$ & $\begin{array}{l}\text { Continuous } \\
\text { Conthly income in Ringgit Malaysia (RM) }\end{array}$ \\
Age & Categorical & $\begin{array}{l}\text { Years of formal education } \\
\text { Dummy variables equal } 1 \text { if the respondent is } \\
\text { single and 0 otherwise }\end{array}$ \\
WTP & Continuous & $\begin{array}{l}\text { Age of respondents in years } \\
\text { Dummy variables equal } 1 \text { if the respondent } \\
\text { accepts the first bid and } 0 \text { otherwise. }\end{array}$ \\
\hline
\end{tabular}


Table 2 Socio-demographic profiles of respondents

\begin{tabular}{|c|c|c|}
\hline \multirow[t]{2}{*}{ Profile } & \multicolumn{2}{|c|}{ Respondent $(\mathrm{n}=300)$} \\
\hline & Frequency & Percentage $(\%)$ \\
\hline \multicolumn{3}{|l|}{ Gender } \\
\hline Male & 255 & 85.0 \\
\hline Female & 45 & 15.0 \\
\hline \multicolumn{3}{|l|}{ Age (years) } \\
\hline 20 and below & 7 & 2.3 \\
\hline $21-30$ & 40 & 13.3 \\
\hline $31-40$ & 50 & 16.7 \\
\hline $41-50$ & 53 & 17.7 \\
\hline $51-60$ & 87 & 29.0 \\
\hline $61-70$ & 63 & 21.0 \\
\hline$>70$ & - & - \\
\hline \multicolumn{3}{|l|}{ Race } \\
\hline Malay & 295 & 98.3 \\
\hline Chinese & 4 & 1.3 \\
\hline Indian & 1 & 0.3 \\
\hline \multicolumn{3}{|l|}{ Marital status } \\
\hline Single & 46 & 15.3 \\
\hline Married & 254 & 84.7 \\
\hline \multicolumn{3}{|l|}{ Household size } \\
\hline 1 & 15 & 5.0 \\
\hline 2 & 18 & 6.0 \\
\hline $3-5$ & 177 & 59.0 \\
\hline $6-8$ & 78 & 26.0 \\
\hline 9 and above & 12 & 4.0 \\
\hline \multicolumn{3}{|l|}{ Individual income (RM) } \\
\hline 500 and below & 63 & 21.0 \\
\hline $501-1000$ & 171 & 57.0 \\
\hline $1001-2000$ & 53 & 17.7 \\
\hline $2001-3000$ & 11 & 3.7 \\
\hline More than 3000 & 2 & 0.7 \\
\hline \multicolumn{3}{|l|}{ Education level } \\
\hline Informal school & 17 & 5.7 \\
\hline Primary school (6 years) & 100 & 33.3 \\
\hline Lower secondary school (9 years) & 64 & 21.3 \\
\hline Upper secondary school (11 years) & 119 & 39.7 \\
\hline
\end{tabular}

their willingness to pay and gave the reason as "to conserve and preserve mangroves and the mangrove biodiversity of Kuala Perlis". The second highest number of respondents who gave the reason as "to ensure that mangroves can be used for future generations" was 53 (or 21.8\%). Two other reasons given were "to conserve Kuala Perlis and other mangrove forests" (21 respondents or 8.6\%) and "as a contribution towards conservation management" (18 respondents or $7.4 \%$ ).

\section{Reasons for not paying}

Table 4 shows that out of a total of 57 respondents, 28 of them (or $49.1 \%$ ) were not willing to pay the first bid value because they believed that the cost of conservation should be borne by the government. It was also found that $33.3 \%$ believed that they could not afford to pay. The other two reasons given by the respondents for non-willingness to pay are also listed in Table 4. 
Table 3 Reasons for paying

\begin{tabular}{lcc}
\hline Reasons & \multicolumn{2}{c}{ Total $\mathrm{n}=243$} \\
& Number & Percentage (\%) \\
\hline To conserve and preserve mangroves and the mangrove & 151 & 62.1 \\
biodiversity of Kuala Perlis & 21 & 8.6 \\
To conserve Kuala Perlis and other mangrove forests & 18 & 7.4 \\
As a contribution towards conservation management & 53 & 21.8 \\
To ensure that mangroves can be used for future generations & & \\
\hline
\end{tabular}

Table 4 Reasons for not paying

\begin{tabular}{lcc}
\hline \multicolumn{1}{c}{ Reasons } & \multicolumn{2}{c}{ Total $\mathrm{n}=57$} \\
\cline { 2 - 3 } & Number & Percentage $(\%)$ \\
\hline Unable to afford & 19 & 33.3 \\
Willing to pay but not at the given price & 9 & 15.8 \\
Willing to pay but in another way & 1 & 1.8 \\
Conservation cost should be the & 28 & 49.1 \\
government's responsibility & & \\
\hline
\end{tabular}

\section{Determinants of willingness to pay}

This section discusses the WTP as stated by the fishermen. Logit regression was used to analyse the significant variables to determine mangrove conservation among fishermen. Table 5 represents the coefficient value for parameters of estimates on willingness to pay at the first bid proposed. This study found that the determinants of WTP for mangrove conservation were bid level, education level and marital status. Other variables that include income, gender and age did not influence WTP.

In terms of bid price, the higher value of the first bid proposed to pay for the conservation of Kuala Perlis also tended to be rejected by the respondents. In Table 5, the bid price shows a negative sign for its coefficient which means that there is an inverse relationship between the variable and WTP. The table shows that the bid price variable is significant at $1 \%$ level. The results from this study were consistent with demand theory which indicates that when the bidding price increases, the respondent WTP for conservation decreased. This result was identical with the study by Kaffashi et al. (2015), Mamat et al. (2013), Kaffashi et al. (2011).

Higher education level may constitute with better awareness on mangrove conservation. Sawairnathan and Halimoon (2017) found that educated people are more willing to support the conservation of mangroves. In addition, Braga et al. (2017) found that fishermen with higher educational level possess more positive attitudes in relation to environmental conservation issues. Single respondents were also found to give positive responses to the first bid suggested. Fatin et al. (2017) found that single respondents were willing to pay more for conservation, compared to married respondents. On the other hand, Lalika et al. (2017) found that married respondents were willing to pay more for watershed conservation.

This study found that income did not influence WTP. The findings showed that fishermen were willing to conserve the mangrove regardless of their income level. Several studies also showed similar results where income did not determine WTP (Wen and Huang 2016, Nguyen and Hoang, 2017). For instance, Wen and Huang (2016) observed that income is not a variable that influences the willingness of consumers to pay for green services or products while, Nguyen and Hoang (2017) found that income does not affect willingness to pay for social health insurance in Vietnam. Based on the description above, this study found a positive influence of belief on WTP. When consumers believed in the benefits of green services provided by green hotels, consumers will be willing to pay for the services, 
Table 5 Interaction for logit regression model

\begin{tabular}{lccc}
\hline Variables & Coefficient & Standard Error & p value \\
\hline Constant & 2.899 & 0.849 & 0.001 \\
\hline Bid & -0.133 & 0.023 & $0.000^{*}$ \\
Education level & 2.683 & 0.754 & $0.000^{*}$ \\
Marital status & 1.590 & 0.777 & $0.041^{* *}$ \\
Income & 0.006 & 0.001 & 0.666 \\
Gender & 0.204 & 0.136 & 0.134 \\
Age & 0.035 & 0.080 & 0.656 \\
Pseudo R & 0.2653 & & \\
Log likelihood & -105.097 & & \\
\hline
\end{tabular}

Note: $* *$ significant at $5 \%$ level, $*$ significant at $1 \%$ level

regardless of their level of income. In addition, the results of other studies found that income can be a moderator between belief and WTP. The findings showed that consumers' income levels did not affect WTP for green services, especially if consumers care about the environment (Nguyen and Hoang 2017).

A large pseudo $\mathrm{R}^{2}$ value indicates a better model fit, where McFadden's pseudo R-squared value, ranging from 0.2 to 0.4 , indicates a very good model fit (Christie et al. 2004, Jin et al. 2006). According to Table 5 , pseudo $\mathrm{R}^{2}$ value for this model is good at 0.2653 .

\section{CONGLUSION}

Mangroves represent a unique ecosystem in coastal areas. They support a rich biodiversity and provide a range of nature's contributions to people, including provisioning, regulating and supporting, all of which are crucial for the sustenance of local communities. Mangroves provide several necessities as part of estuarine and coastal ecosystems. They contribute significantly to commercial fisheries by providing breeding and nursery grounds, aside from safeguarding our shorelines from strong winds, erosion and currents. Mangroves also offer other functions such as forming a buffer from siltation to protect offshore coral reefs, hence affecting productivity of the reefs. In addition, the services provided by a mangrove ecosystem are beneficial for socio and economic development.

Besides bid level, this study indicates sociodemographic factors; educational level and marital status play an important role and may influence the respondent's WTP towards conservation of nature in Kuala Perlis. The results provide information that conservation fee (or any conservation price) is the main concern among the fishermen in the area. However, this finding is not homogeneous; different demographics possibly resulted in various respondents' WTP. This study also illustrated that, in undertaking efforts to conserve mangrove ecosystems, it is important to have the support of those communities which most depend on mangroves to earn livelihoods. The fishermen of Kuala Perlis represent just such a community. In terms of the practicality, this research provides information to policy makers in planning successful programs for mangrove conservation in the area by considering factors influencing WTP among the community. The findings also support in designing conservation guideline to ensure the sustainability of the mangrove forest.

\section{ACKNOWLEDGEMENTS}

The authors would like to thank JTRD fund vote 9441203 for the financial support given to conduct this study, and the Director of Perlis Forestry Department for approving the use of the mangrove forest in Perlis as the study site.

\section{REFERENCES}

Ajzen I \& Driver BL. 1992. Contingent value measurement: On the nature and meaning of willingness to pay. Journal of Consumer Psychology 1: 297-316.

Alberini A \& KAHN JR. 2006. Handbook on Contingent Valuation. Edward Elgar, Cheltenham

Arrow KJ, Solow R, Learner E, Portney P, Radner R \& Schuman H. 1993. Report of the NOAA panel 
on contingent valuation. US Federal Register 58: 4601-4614.

Aswad M, Radam A, Yacob MR \& Yahya NA. 2011. Willingness to pay towards the sustainability of Forest Research Institute Malaysia's (FRIM's) canopy walkway. Social Sciences 2: 85-92.

Aтім C. 1999. Social movements and health insurance: a critical evaluation of voluntary, non-profit insurance schemes with case studies from Ghana and Cameroon. Social Science E Medicine 48: 881-896.

Bhandari AK \& Heshmati A. 2010. Willingness to pay for biodiversity conservation. Journal of Travel and Tourism Marketing 27: 612-623.

Baral N, Stern MJ \& Bhattarai R. 2008. Contingent valuation of ecotourism in Annapurna conservation area, Nepal: implications for sustainable park finance and local development. Ecological Economics 66: 218-227.

Barbier EB, Hacker SD, Kennedy C, Koch EW, Stier AC \& Silliman BR. 2011. The value of estuarine and coastal ecosystem services. Ecological monographs 81: 169-193.

BARBIER EB. 1994. Valuing environmental functions: tropical wetlands. Land Economics 70: 155-173.

Bhandari AK \& Heshmati A. 2010. Willingness to pay for biodiversity conservation. Journal of Travel and Tourism Marketing 27: 612-623.

Bloom G \& Shenglan T. 1999. Rural health prepayment schemes in China: towards a more active role for government. Social Science Ẽ Medicine 48(7): 951-960.

Bowker JM, Cordell HK \& Johnson CY. 1999. User fees for recreation services on public lands: a national assessment. Journal of Park and Recreation and Administration 17: 1-14.

Braga HO, Azeiteiro UM, Oliviera HM, Pardal Ma. 2017. Evaluating fishermen's conservation attitudes and local ecological knowledge of the European sardine (Sardina pilchardus). Journal of Ethnobiology and Ethnomedicine 13: 25.

Brander L \& EpPInk F. 2012. The economics of ecosystems and biodiversity for Southeast Asia (ASEAN TEEB). Scoping study prepared for GIZ and ACB, Laguna, Philippines. http:/ / www. aseanbiodiversity. org.

Costanza R, Darge R, De Groot R, et al. 1997. The value of the worlds ecosystem services and natural capital. Nature 387: 253-260.

DAS S \& CREPIN AS. 2013. Mangroves can provide protection against wind damage during storms. Estuarine, Coastal and Shelf Science 134: 98-107.

Desvousges WH, Gable AR, Dunford RW \& Hudson SP. 1993. Contingent valuation: the wrong tool to measure passive-use losses. Choices 8: 9-11.

Dong X, Zhang J, Zhi R, Zhong SE \& Li M. 2011. Measuring recreational value of world heritage sites based on contingent valuation method: a case study of Jiuzhaigou. Chinese Geographical Science 21: 119-128.

EzebiLo E. 2016. Willingness to pay for maintenance of a nature conservation area: a case of Mount Wilhelm, Papua New Guinea. Asian Social Science, 12: 149-161.

Fatin R, Zaiton S \& Awang-Noor G. 2017. willingness to pay for conservation fee using contingent valuation method: the case of Matang Mangrove Forest Reserve, Perak, Malaysia. Malaysian Forester 80: 99-110.
Garrod G \& Willis K. 1999. Economic Valuation of the Environment: Methods and Case Studies. Edward Elgar, Cheltenham.

Google Earth. (2019). https://earth.google.com/web/@ $6.38696555,100.13723422,6.53707586 \mathrm{a}, 4836.29313$ $781 \mathrm{~d}, 35 \mathrm{y}, 0 \mathrm{~h}, 0 \mathrm{t}, 0 \mathrm{r}$

Groot RD, Brander L, Ploeg SVD et al. 2012. Global estimates of the value of ecosystems and their services in monetary units. Ecosystem Services 1: 50-61.

Fisheries DePARTMENT. 2017.

https://www.dof.gov.my/dof2/resources/user_29/ Documents / Perangkaan\%20Perikanan2016/ Nel_Vesel2.pdf

Hanemann M, Loomis J \& Kanninen B. 1991. Statistical efficiency of doublebounded dichotomous choice contingent valuation. American Journal of Agricultural Economics 73: 1255-1263.

Hejazi R, Shamsudin MN \& Rahim KA. 2014. Measuring the economic values of natural resources along a freeway: a contingent valuation method. Journal of Environmental Planning and Management 57: 629-641.

Jin J, He R, Gong H \& WANG W. 2018. Role of risk preferences in explaining the public's willingness to pay for marine turtle conservation in China. Ocean and Coastal Management 160: 52-57.

Jin J, WANG Z \& RAN S. 2006. Solid waste management in Macao: practices and challenges. Waste Manage 26: 1045-1051.

Kaffashi S, Shamsudin MN, Radam A, Rahim KA, Yacob MR, Muda A, YAzId M. 2011. Economic valuation of Shadegan International Wetland, Iran: notes for conservation. Regional Environmental Change 11: 925-934.

Kaffashi S, Yacob MR, Clark MS, Radam A \& Mamat MF. 2015. Exploring visitors' willingness to pay to generate revenues for managing the National Elephant Conservation Center in Malaysia. Forest Policy and Economics 56: 9-19.

KAMRI T. 2013. Willingness to pay for conservation of natural resources in the Gunung Gading National Park, Sarawak. Procedia-Social and Behavioral Sciences 101. 506-515.

Khan H \& Giurca VL. 2008. The willingness to pay for recreational services: an empirical investigation with the application of multivariate analysis of two public parks in Northern Pakistan.

Lalika MCS, Meire P, Ngaga YM \& Sanga GJ. 2017. Willingness to pay for watershed conservation: are we applying the right paradigm? Eco Hydrology and Hydrobiology 17: 33-45.

Landry EC, Keeler A \& Kriesel W. 2003. An economic evaluation of beach erosion management alternatives. Marine Resource Economics 18: 105-127.

Langford IH, Kontogianni A, Skourtos MS, Georgiau S \& Bateman IJ. 1998. Multivariate mixed models for open ended contingent valuation data: willingness to pay for conservation of monk seals. Environmental Resource Ẽ Economics 12: 443-456.

Mamat MP, Yacob MR, Radam A, Ghani ANA \& Fui LH. 2013. Willingness to pay for protecting natural environments in Pulau Redang Marine Park, Malaysia. African Journal of Business Management 7: 2420. 
Mitchell RC \& Carson RT. 1989. Using Surveys to Value Public Goods: The Contingent Valuation Method. Resources for the Future, Washington DC.

Nguyen LH \& Huang ATD. 2017. Willingness to pay for social health insurance in central Vietnam. Frontiers in Public Health 5: 89.

Pampel FC. 2000. Logistic Regression: A Primer. Volume 132. Sage Publications, Thousand Oaks, California.

Parid MM, Lim HF, Huda Farhana MM, Mukrimah A \& Mubarak HT. 2014. Assessing The Conservation Value of the Mangrove Forest Ecosystem. Pp 81-85 in Rahim S et al. Proceedings of the Conference On Forestry and Forest Products Research 2013. 12-13 November 2013, Kuala Lumpur.

Pearce DW \& Turner RK. 1990. Economics of natural resources and the environment. JHU Press, Maryland.

Rathnayake RMW. 2016. Turtle watching: a strategy for endangered marine turtle conservation through community participation in Sri Lanka. Ocean and Coastal Management 119: 199-207.

Sawairnathan MI \& Hahlimoon N. 2017. Assessment of the local communities' knowledge on mangrove ecology. Internatioanl Journal of Human Capital in Urban Management 4: 125-138.

SEKARAN U. 1992. Research method for measuring consumer perceptions of service quality. Journal of Retailing 57: $15-17$.

Shervette VR, Aguirre WE, Blacio E, Cevallos R, Gonzalez M, Pozo F \& Gelwick F. 2007 Fish communities of a disturbed mangrove wetland and an adjacent tidal river in Palmar, Ecuador. Estuarine Coastal and Shelf Science 72: 115- 128.

TEEB (The Economics of Ecosystems and Biodiversity) Foundation. 2010. The Economics of Ecosystems and Biodiversity: Ecological and Economic Foundations. Earthscan, London.

Tisdell C \& Wilson C. (2000). Astudy of the impact of ecotourism on environmental education and conservation: The case of turtle watching of an Australian site. Working paper on economics, ecology and the environment, University of Queensland, Queensland.

Tongco MDC. 2007. Purposive sampling as a tool for informant selection. Ethnobotany Research $\mathcal{E}^{\circ}$ Applications 5: 147-158.

Vegh T, Jungwimattanaporn M, Pendleton L \& Murray BC. 2014. Mangrove Ecosystem Services Valuation: State of The Literature. Duke University, Durham, NC.

WANG PW \& JIA JB. 2012. Tourists' willingness to pay for biodiversity conservation and environment protection, Dalai Lake protected area: Implications for entrance fee and sustainable management. Ocean E Coastal Management 62: 24-33.

Well S, Ravilious C \& Corcoran E. 2006. In the Front Line: Shoreline Protection and Other Ecosystem Services from Mangroves and Coral Reefs. UNEP-WCMC, Cambridge.

WEN YF \& Huang YT. 2018. Study on the background and trust factors of willing-to-buy the energy option. Asia Pacific Management Review 24: 1-13.

White PCL \& Lovett JC. 1999. Public preferences and willingness-to-pay for nature conservation in the North York Moors National Park, UK. Journal of Environmental Management 55: 1-13.

Zaiton S, Herman S, Alias R \& Mohd-Rusli Y. 2012. Willingness to pay for conservation fee at Penang National Park. Malaysian Forester 75: 41-50.

Zaiton S, Yuhanis AA, Alias R \& Mohd RY. 2010. Factors influencing the willingness to pay for entrance permit: The evidence from Taman Negara National Park. Journal of Sustainable Development 3: 212-220.

Zikmund WG, Babin BJ, CARR JC \& GRIFFIn M. 2013. Business Research Method. South Western Cengage Learning, Canada.

Zemedu L \& Mitike A. 2015. Fishermen's Willingness to Pay for Fisheries Management: The Case of Lake Zeway, Ethiopia. $\mathrm{PhD}$ thesis, Haramaya University, Dire Dawa. 